\title{
Effect of the period of extrinsic mechanical compression following sclerotherapy in veins in rabbit ears ${ }^{1}$
}

\author{
Efeito do tempo da compressão mecânica extrínseca após escleroterapia \\ em veias de orelhas de coelhos
}

\author{
Cláudio Santana IvoI, Marcelo Braga Ivo", Paulo Guilherme de Oliveira Salles ${ }^{\mathrm{III}}$, Ricardo Costa Val do Rosário ${ }^{\mathrm{IV}}$, Tarcizo \\ Afonso Nunes $v$
}

${ }^{1}$ Research performed at Surgical and Ophthalmological Applied Sciences Postgraduate Program, Federal University of Minas Gerais (UFMG), Brazil. Part of Master's degree thesis. Mentor: Tarcizo Afonso Nunes

\begin{abstract}
${ }^{I}$ Master, Assistant Professor, Department of Biological, Environmental and Health Sciences at Uni/BH, Minas Gerais, Brazil. Intellectual and scientific content of the study, manuscript writing, involved with technical procedures and in the protocol.

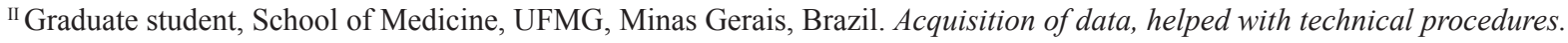

III PhD, Substitute Professor, Department of Pathological Anatomy and Legal Medicine (APM), School of Medicine, UFMG, Minas Gerais, Brazil. Pathological examinations, Histometric examinations, involved in the protocol.

${ }^{\text {IV }}$ PhD, Surgical and Ophthalmological Applied Sciences Postgraduate Program, UFMG, Minas Gerais, Brazil. Acquisition of data, manuscript preparation.

${ }^{\mathrm{V}} \mathrm{PhD}$, Associate Professor, Department of Surgery, School of Medicine, UFMG, Minas Gerais, Brazil. Mentor, conception and design of the study, manuscript writing, critical revision
\end{abstract}

\begin{abstract}
Purpose: Research whether a post-sclerotherapy venous compression period of up to 120 hours is sufficient to avoid reperfusion in treated veins; whether there is a relationship between the inflammatory intensity in venous walls and adjacent tissue and the size of venous thrombosis; whether the intensity of the post-sclerotherapy inflammation varies with the period of compression; whether there is a relationship between the presence of hemosiderin in the tissues adjacent to the sclerosing blood vessels and venous blood clots. Methods: Twenty eight rabbits, all male, were utilized, distributed into four groups (0, 24, 72 and 120). All the animals were administered with $0.25 \mathrm{ml}$ of $1 \%$ polidoconal solution and, as a control, $0.25 \mathrm{ml}$ of $0.9 \%$ sodium chloride solution in the marginal dorsal vein of the right and left ears, respectively. Mechanical compression was applied to the perfused stretch of the vein, except for the animals in group 0. The period of compression varied from 0 to 120 hours in the groups. An anatomopathological examination of the section of the right and left marginal dorsal veins of all the animals was conducted. Results: There was no significant difference among the various compression periods, both in terms of the degree of vein thrombosis and in the inflammatory intensity in both ears of the various groups. A positive and significant correlation was observed between the inflammatory intensity and the size of the thrombus and in the occurrence of thrombi and hemosiderin. Conclusions: A compression period of up to 120 hours is not sufficient to prevent reperfusion in sclerosing blood vessels. The intensity of tissue inflammation is related to the size of the thrombus, but not to the compression period. The presence of hemosiderin in the tissues adjacent to the vessels subjected to sclerosis is related to the presence of venous coagulation.
\end{abstract}

Key words: Sclerotherapy. Sclerosing Solutions. Varicose Veins. Animal Experimentation. Academic Dissertations. Rabbits.

\section{RESUMO}

Objetivo: Pesquisar se o tempo de compressão venosa de até 120 horas pós-escleroterapia é suficiente para evitar reperfusão nas veias tratadas; se há relação entre a intensidade inflamatória na parede venosa e tecidos adjacentes e o tamanho do trombo venoso; se a intensidade da inflamação pós-escleroterapia varia com o tempo de compressão; se há relação entre a presença de hemossiderina nos tecidos adjacentes ao vaso esclerosado e coágulo venoso. Métodos: Utilizaram-se 28 coelhos, machos, distribuídos em quatro grupos $(0,24,72$ e 120). Em todos os animais foram administrados $0,25 \mathrm{ml}$ de solução de polidocanol $1 \%$ e, como controle, $0,25 \mathrm{ml}$ de solução de cloreto de sódio $0,9 \%$ na veia marginal dorsal das orelhas direita e esquerda, respectivamente. Realizou-se compressão mecânica em trecho da veia perfundida, exceto nos animais do grupo 0 . O tempo de compressão variou de 0 a 120 horas nos grupos. Realizou-se exame anatomopatológico de trecho das veias marginais dorsais direita e esquerda de todos os animais. Resultados: Não houve diferenças significativas nos diversos tempos de compressão, tanto no grau de trombose venosa como na intensidade inflamatória, 
em ambas as orelhas, nos diversos grupos. Observou-se correlação positiva e significativa entre intensidade inflamatória e tamanho do trombo e na ocorrência de trombos e hemossiderina. Conclusões: O tempo de até 120 horas de compressão não é suficiente para evitar reperfusão nos vasos esclerosados. A intensidade da inflamação nos tecidos tem relação com o tamanho do trombo, mas não com o tempo de compressão. A presença de hemossiderina nos tecidos adjacentes ao vaso submetido à esclerose está relacionada com a presença de coágulo venoso.

Descritores: Escleroterapia. Soluções Esclerosantes. Varizes. Experimentação Animal. Dissertações Acadêmicas. Coelhos.

\section{Introduction}

Varicose veins are the most common of all vascular alterations. They are conceptualized as dilated, tortuous and elongated veins. Within this concept it is possible to also include subcutaneous reticular varicose veins and telangiectasias, which are dilated intradermic blood vessels.

The treatment for the various varicose veins is still controversial, as there are various therapeutic possibilities. A decision is made in some cases to opt for clinical treatment and, more frequently, for surgical and/or sclerotherapeutic treatment. Operations, sclerosis (chemical, LASER, ENDOLASER, radiofrequency) and a combination of both are employed ${ }^{1}$.

For telangiectasias and reticular varicose veins, sclerosing chemical treatment dominates among the recommendations given, with surgical, radiofrequency and ENDOLASER methods being reserved for the treatment of large caliber varicose veins. However, currently, even with these varicose veins, chemical sclerosing methods have been utilized, especially in relation to sclerosis being monitored through eco-color-Doppler with the administration of dense foam.

It has been observed that, regardless of whether surgical or sclerotherapeutic treatment was recommended and of the reason for the recommendation, there is always an attempt to associate good functional results with good esthetic results. Therefore, preventing the occurrence of post-treatment dermal hyperpigmentation is fundamental. There is a consensus that, following sclerotherapy, this complication should be attributed to the impregnation of the skin with hemosiderin, released by the degradation of the red blood cells present in the intravascular thrombi, which normally occur following endovenous injections of sclerosing substances.

For this reason, following sclerotherapy, it is common to utilize extrinsic compression to prevent or reduce the formation of clots within the sclerosed blood vessel with the goal of preventing the formation of dermal macules due to hemosiderin impregnation. These compressions are maintained for hours, days or even a few weeks, depending on the of the therapist's background experience.

It has been observed that if the compressive method is not maintained for a sufficient period, the blood may reperfuse the treated vein, coagulating as it contacts the endothelial lesion caused by the action of the sclerosing substance and result in the formation of a dermal macule.

This research, in an experimental character, has the objective of contributing towards the treatment of varicose veins in the lower limbs, especially as relates to the definition of the points that are controversial and still in need of further work in scientific publications, mainly related to the period during which the post-sclerotherapy venous compression should be maintained.

The following points were researched:

- Whether a post-sclerotherapy venous compression period of up to 120 hours is sufficient to prevent blood reperfusion in the treated veins;

- Whether there is a relationship between the intensity of the post-sclerotherapy inflammation of the venous walls and the adjacent tissues and the size of the venous thrombus;

- Whether there is a relationship between the presence of hemosiderin in the tissues adjacent to the sclerosed vein and the clot in the venous lumen;

- Whether the intensity of the post-sclerotherapy inflammatory process varies with the period of compression.

\section{Methods}

The research project was approved by the Chamber of the Surgery Department of the School of Medicine at UFMG and by Animal Experimentation Ethics Committee, protocol \# 184/2006.

\section{Experimental delineation}

The research was performed on 28 rabbits of the species Oryctolagus cuniculus, of a New Zealand line. All of them were young adult males weighing between 1.5 and $3.0 \mathrm{~kg}$. The sample number was based on the experimental model utilized and on the statistical methods that were to be employed for the analysis of the results.

The rabbits were identified with the numbers 1 to 28 , via a draw, and distributed into four groups of seven animals, with the period of compression and number of animals having been previously established in the manner shown below: 
- Group 0 (no compression) - animals numbered 1 to 7;

- Group 24 (compression for 24 hours) - animals numbered 8 to 14 ;

- Group 72 (compression for 72 hours) - animals numbered 15 to 21 ;

- Group 120 (compression for 120 hours) - animals numbered 22 to 28 .

All the animals were administered $0.25 \mathrm{ml}$ of a sclerosing solution of $1 \%$ polidoconal in liquid form in the marginal dorsal venous lumen of the right ear and $0.25 \mathrm{ml}$ of a sodium chlorate solution in the marginal dorsal venous lumen of the left ear as a control. Each ear corresponded to a sampling unit.

\section{Compression of the veins}

All the animals, except those in group 0, were subjected to mechanical compression on the segment of the vein in which one of the solutions had been administered, employing a device specially designed for this purpose (Figure 1).

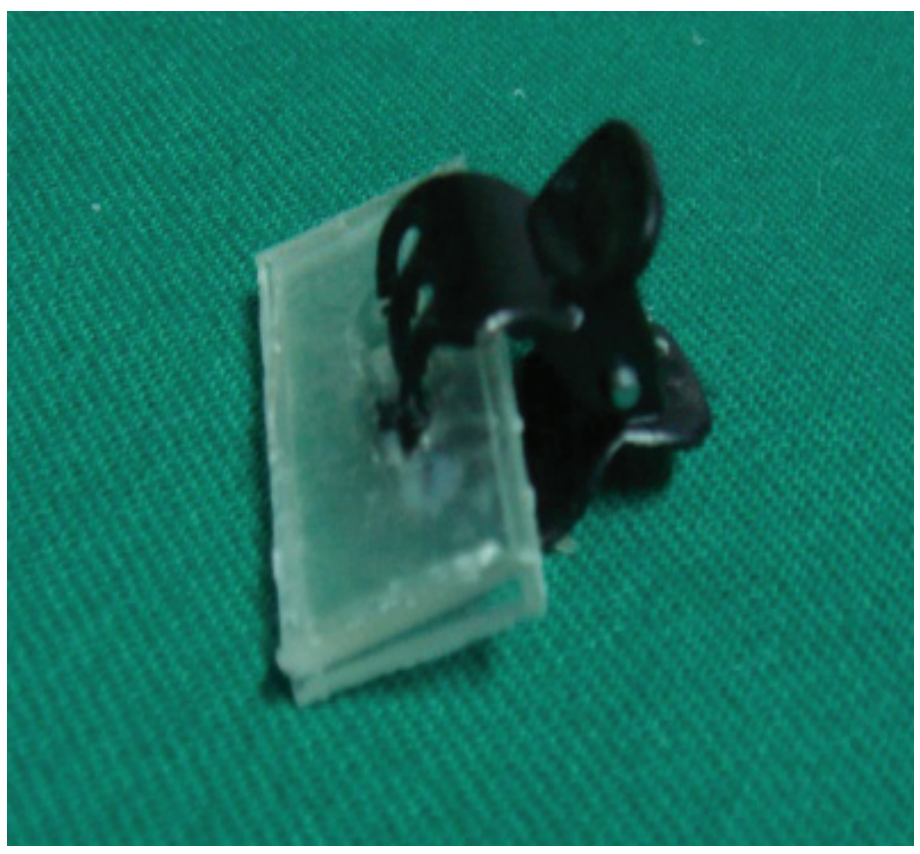

FIGURE 1 - Photograph of the compression device composed of transparent plastic plates affixed using a small claw equipped with a spiral spring that provides compression between the two plastic plates.

The compression covered 0.625 to 0.75 inches of the vein, 0.75 inches from the puncture location. The transparent plates in the compression device allowed for visualization of the compressed section of the vein, thus certifying the effectiveness of the compression (Figure 2).
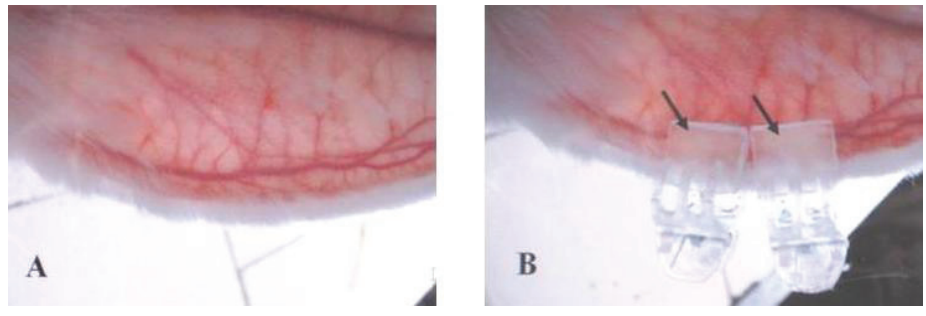

FIGURE 2 - Photograph of the rabbit ear showing the marginal dorsal vein without (A) and with (B) the compression device. Note, via the transparency of the device, that the section of vein is adequately squeezed by the compression device (arrows).

The period of compression was 24 hours for the animals in group 24, 72 hours for those in group 72 and 120 hours for those in group 120. For the animals in group 0, no compression was applied.

\section{Measurement of the compressive force of the}

compression devices

Eight compression devices were utilized, the pressure force of which was measured using the smallest pressure transducer made by Kikuhime (portable apparatus for monitoring bandage pressure - MediTrade, Soro, Denmark). In accordance with the specification of the measurement device, following calibration, five pressure measurements were taken for each device to establish the average pressure. As the results of the pressure measurements did not present a normal distribution, verified using the Lilliefors Test, the non-parametric Kruskall-Wallis Test was utilized, which showed that there was no significant difference in pressure between the various compression devices utilized $(\mathrm{p}>0.05)$ (Table 1).

TABLE 1 - Pressure measurements for the compression devices in $\mathrm{mmHg}$.

\begin{tabular}{|c|c|c|c|c|c|c|}
\hline \multirow[t]{2}{*}{ Device } & \multicolumn{5}{|c|}{$\begin{array}{l}\text { Pressure measurements } \\
\text { in } \mathrm{mmHg}\end{array}$} & \multirow{2}{*}{$\begin{array}{l}\text { Average pressure } \\
\text { in } \mathrm{mmHg}\end{array}$} \\
\hline & $1^{\text {st }}$ & $2^{\text {nd }}$ & $3^{\text {rd }}$ & $4^{\text {th }}$ & $5^{\text {th }}$ & \\
\hline$\#-1$ & 9 & 8 & 8 & 8 & 8 & 8.2 \\
\hline$\#-2$ & 8 & 7 & 8 & 7 & 7 & 7.4 \\
\hline$\#-3$ & 7 & 7 & 7 & 7 & 7 & 7.0 \\
\hline$\#-4$ & 8 & 7 & 8 & 8 & 7 & 7.6 \\
\hline$\#-5$ & 8 & 8 & 8 & 8 & 7 & 7.8 \\
\hline$\#-6$ & 7 & 8 & 8 & 8 & 7 & 7.6 \\
\hline$\#-7$ & 7 & 7 & 8 & 8 & 7 & 7.4 \\
\hline \#- 8 & 9 & 8 & 8 & 8 & 8 & 8.2 \\
\hline
\end{tabular}




\section{Craniocervical isolation}

For the animals in group 0, which were not subjected to venous compression, there was no need for craniocervical isolation. For the others, this isolation was performed utilizing a device specially designed for this purpose ${ }^{2}$, with the purpose of preventing the animal from removing the compression devices (Figure 3).

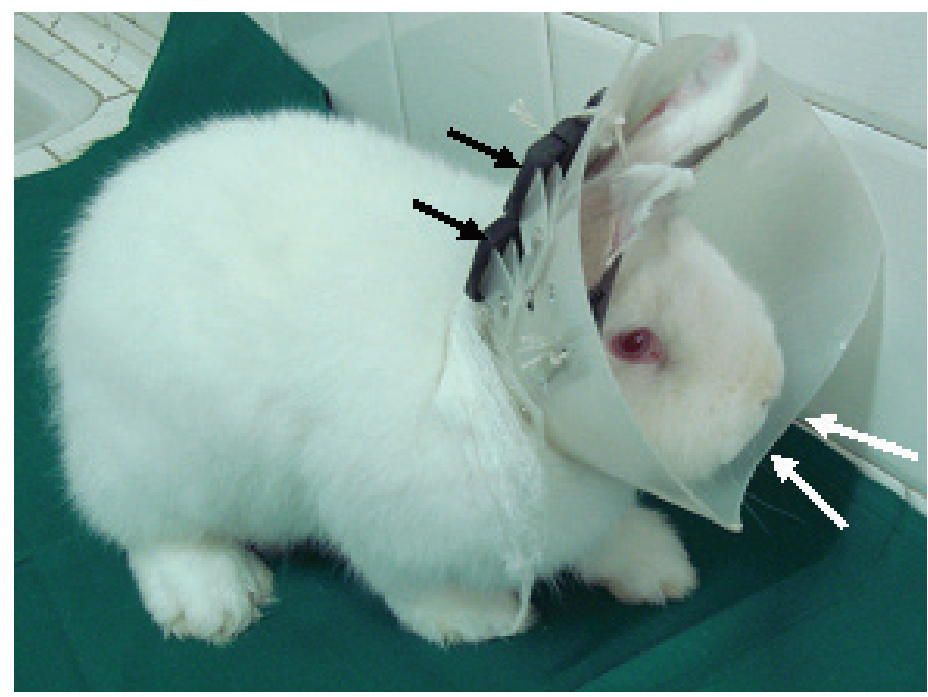

FIGURE 3 - Photograph of a rabbit with the craniocervical isolation collar.

Euthanasia of the animals and amputation of the ears

Twenty-four hours after the endovenous administration of the solutions in the veins in the ears of the animals in group 0 (without compression) and 24 hours after removing the vein compression devices from the animals in the other three groups, the animals were euthanized.

Following euthanasia, a 0.625 inches-long and 0.375 inches-wide segment of the ear, encompassing the section of the marginal dorsal vein, was collected for an anatomopathological exam. A sample 0.75 inches from the puncture location was chosen in order to avoid the presence of red blood cells resulting from any leakage of blood at that site (Figure 4).

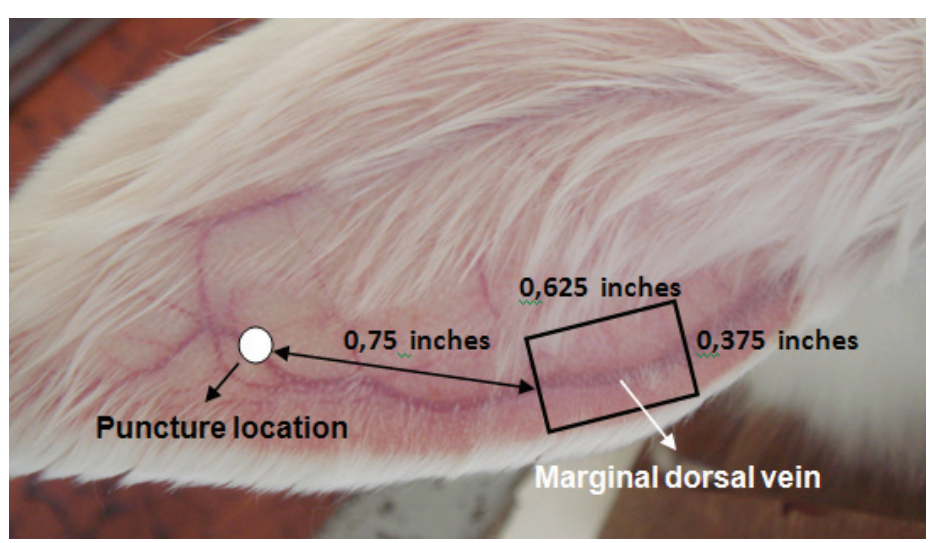

FIGURE 4 - Photograph of the left ear of a rabbit, identifying the marginal dorsal vein, the puncture location and the section of the ear that is to undergo an anatomopathological exam (rectangle).

\section{Anatomopathological study}

The findings of the histology were registered and took into consideration: the venous obstruction by thrombi in the venous lumen; the intensity of the inflammatory process in the blood vessel and neighboring tissues; the presence or lack of hemosiderin in the tissues adjacent to the blood vessel that received the endovenous injection.

The degree of venous obstruction by thrombosis was evaluated in percentage terms using an optical microscope (Figure 5).

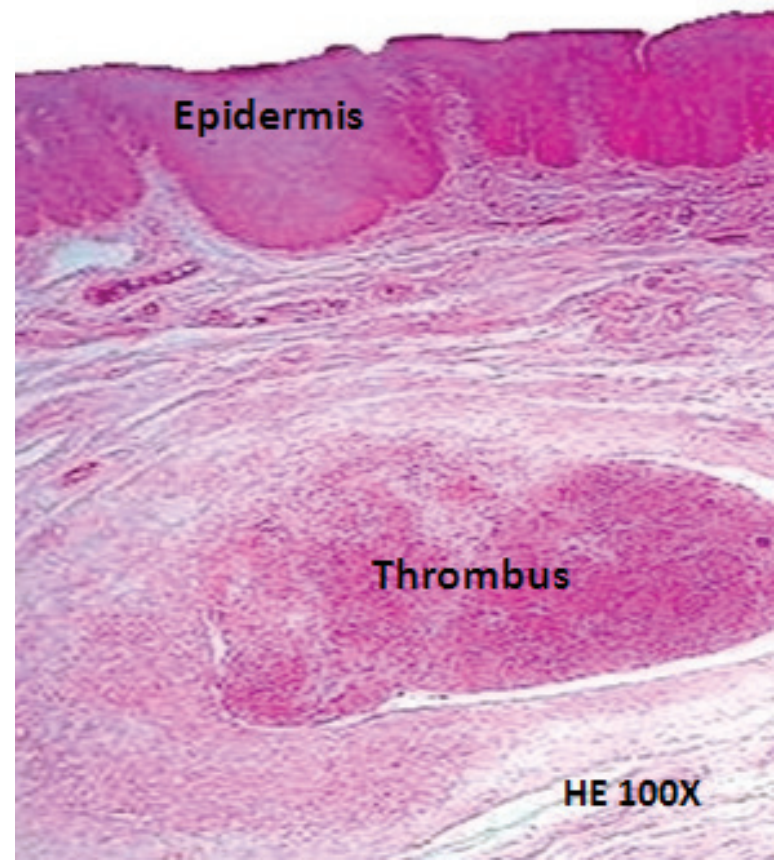

FIGURE 5 - Histological section of the transverse segment of vein, 100x magnification, showing presence of thrombus almost completely occluding intravasal lumen $(>75 \%=$ Class 4$)$. 
Classes of 0 to 4 were defined in accordance with the percentage of obstruction observed with the following correspondence (Table 2):

TABLE 2 - Correspondence of the classes with the venous obstruction percentages observed in the histological study.

\begin{tabular}{cc}
\hline CLASS & $\begin{array}{c}\text { DEGREE OF OBSTRUCTION } \\
(\%)\end{array}$ \\
\hline 0 & 0 \\
1 & $1-25$ \\
2 & $26-50$ \\
3 & $51-75$ \\
4 & $>75$ \\
\hline
\end{tabular}
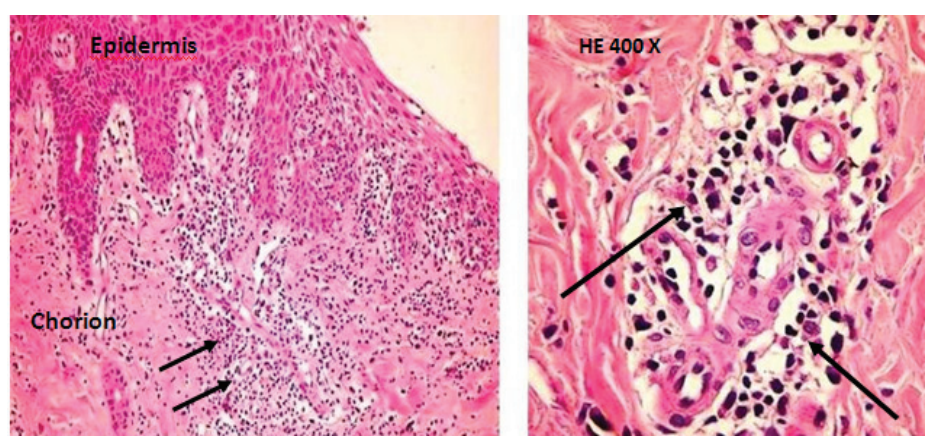

FIGURE 6 - Histological section, stained with hematoxylin-eosin, 400x and 100x magnification, which evident inflammatory process - black arrows - (class $2=$ moderate) located on chorion and predominantly perivascular and mononuclear.

For the evaluation of the intensity of inflammation of the vein and neighboring tissues, classes from 0 to 3 were defined in the optical microscope exam (Figure 6), quantified by analogy with a well known study ${ }^{3}$ with well defined criteria and previously tested reproductivity ${ }^{4}$, such as: absent, discrete, moderate and accentuated (Table 3).
TABLE 3 - Relationship between the degree of inflammation of the veins and the class.

\begin{tabular}{cc}
\hline CLASS & $\begin{array}{c}\text { DEGREE OF } \\
\text { INFLAMMATION }\end{array}$ \\
\hline 0 & Absent \\
2 & Discrete \\
3 & Moderate \\
\hline
\end{tabular}

Hemosiderin was evidenced via optical microscope through the identification of granules of nuttish brown coloration located in the tissues adjacent to the vein in which the pharmacological substances were injected, and microscope slides of which were stained with H\&E stain (Figure 7). There was the following correspondence for the presence or lack of hemosiderin: $0=$ absent, 1 = present, but not quantified.
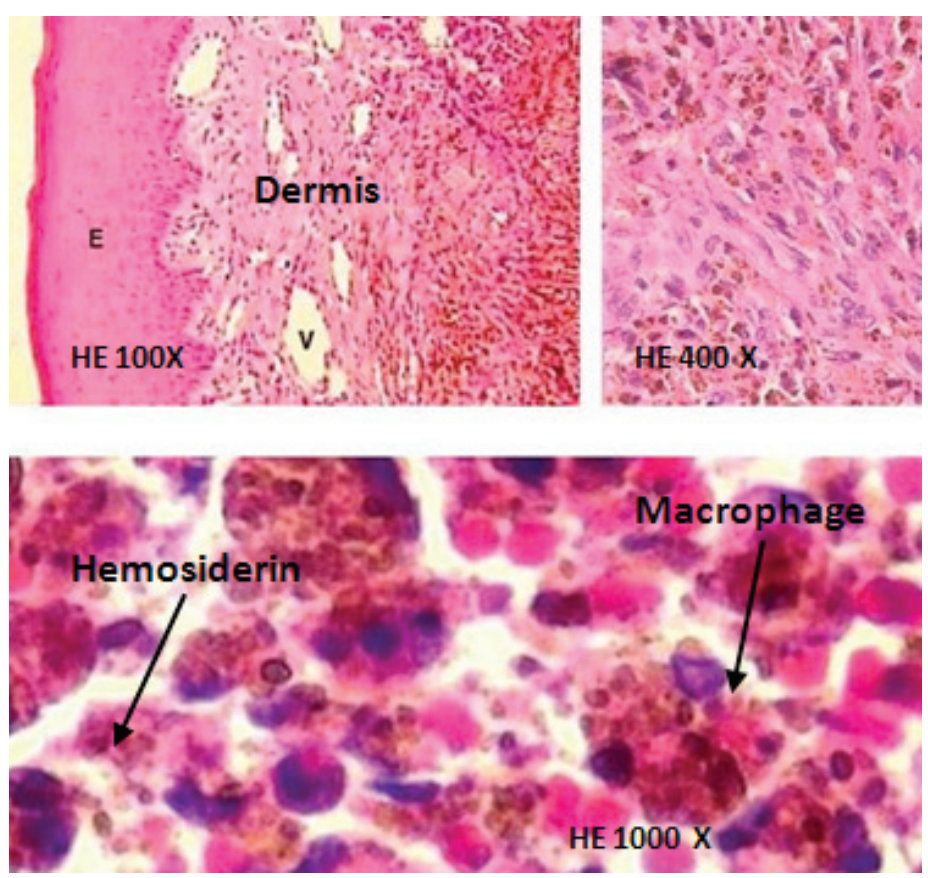

FIGURE 7 - Histological section, 100x, 400x and 1000x magnification, stained with hematoxylin-eosin, demonstrating hemosiderin granules, pale brown-brown, located in the dermis and inside macrophages. 


\section{Variables studied and statistical tests}

The variables in this research were of a qualitative nature and the strategies for the statistical analysis were of a nonparametric character, or that is:

a) The degree of vein obstruction by thrombus in the vein lumens for the different compression periods was evaluated by means of rank correlation studies and the Kruskall-Wallis Test at $\mathrm{p}<0.05$;

b) The analysis of the results related to the intensity of the inflammatory process in the blood vessel and the neighboring tissues for the different compression periods was also performed by means of rank correlation studies and the Kruskall-Wallis Test at $\mathrm{p}<0.05$;

c) The correlation between the presence or absence of hemosiderin in the tissues adjacent to the blood vessel that received the endovenous injection and the presence or absence of thrombus in the vein lumen was studied by means of the Chi-square Test;

d) The correlation between the intensity of the inflammatory process and the size of the thrombus was studied using the Kendall correlation method as they are the two responses of a qualitative nature, measured by score variations.

\section{Results}

\section{Degree of obstruction by venous thrombosis}

A comparison of the averages of the scores for the degree of vein obstruction in each group of animals in the various compression period groups, including the group without compression, both for $1 \%$ polidocanol and for $0.9 \%$ sodium chlorate (control), did not result in significant differences $(\mathrm{p} \geq 0.05$ ) (Table 4).

TABLE 4 - Comparison of the averages of the scores for the degree of vein obstruction by thrombi for each medication employed in the various compression period groups.

\begin{tabular}{ccccc}
\hline \multirow{2}{*}{ Medications } & \multicolumn{4}{c}{ Compression period (hours) } \\
\cline { 2 - 5 } & 0 & 24 & 72 & 120 \\
\hline $\begin{array}{c}0.9 \% \text { Podidocanol } \\
\begin{array}{c}0.29^{\mathrm{A}} \\
\text { chlorate solution }\end{array}\end{array}$ & $2.29^{\mathrm{A}}$ & $2.14^{\mathrm{A}}$ & $2.0^{\mathrm{A}}$ \\
\hline
\end{tabular}

- Means followed by the same letters, in the lines, do not differ statistically amongst themselves;

- Capital letters refer to in-line comparisons (compression period for the same pharmacological substance), using the Kruskall-Wallis test, considered significant when $\mathrm{p}<0.05$.

Comparison between the different compression periods concerning the inflammation of the vein and neighboring tissues

A comparison of the averages of the scores for the degree of inflammation of the blood vessels and neighboring tissues, for the various compression periods, including the group without compression, did not result in significant differences $(\mathrm{p} \geq 0.05)$, either for the $1 \%$ polidocanol or for the $0.9 \%$ sodium chlorate (control) (Table 5).

TABLE 5 - Comparison of the averages of the scores for the degree of inflammation of the venous walls and neighboring tissues among the different compression periods for each medication used.

\begin{tabular}{|c|c|c|c|c|}
\hline \multirow{2}{*}{ Medication } & \multicolumn{4}{|c|}{ Compression period (Hours) } \\
\hline & 0 & 24 & 72 & 120 \\
\hline 1\% Polidocanol & $1.86^{\mathrm{A}}$ & $3.0^{\mathrm{A}}$ & $2.71^{\mathrm{A}}$ & $2.43^{\mathrm{A}}$ \\
\hline $\begin{array}{c}0.9 \% \text { Sodium } \\
\text { chlorate solution }\end{array}$ & $1.57^{\mathrm{A}}$ & $2.43^{\mathrm{A}}$ & $2.71^{\mathrm{A}}$ & $2.29^{\mathrm{A}}$ \\
\hline
\end{tabular}

- Averages followed by the same letters, in the lines, do not differ statistically amongst themselves;

- Capital letters refer to in-line comparisons (compression period for the same pharmacological substance), using the Kruskall-Wallis test, considered significant when $\mathrm{p}<0.05$.

Association between the presence of thrombus and hemosiderin

A significant association ( $p=0.0238)$ was observed between the presence of hemosiderin in the tissues adjacent to the vein that received an injection of pharmacological substances and the presence of venous thrombus, indicating a risk attributed at $35.71 \%$ of the occurrence of pigment in the presence of clots (Table 6). 
TABLE 6 - Relation between the absence of presence of thrombus with the absence or presence of hemosiderin in the tissues adjacent to the infused blood vessel.

\begin{tabular}{cccc}
\hline \multirow{2}{*}{$\begin{array}{c}\text { Venous } \\
\text { Thrombus }\end{array}$} & \multicolumn{2}{c}{ Hemosiderin } & \multirow{2}{*}{ Total } \\
\cline { 2 - 3 } & Absent & Present & \\
\hline Absent & $15(78.95 \%)$ & $4(21.05 \%)$ & $19(100 \%)$ \\
Present & $16(43.24 \%)$ & $21(56.76 \%)$ & $37(100 \%)$ \\
Total & 31 & 25 & 56 \\
\hline
\end{tabular}

Correlation between the inflammatory intensity and size of the thrombus

The relationship between the inflammatory intensity in the blood vessel and neighboring tissues and the size of the thrombus, in an evaluation of the 56 rabbit ears, demonstrated a correlation that was positive of $0.2932(29.32 \%)$ and significant $(\mathrm{p}=0.0007)$, when evaluated using the Kendall non-parametric Correlation Test.

\section{Discussion}

Sclerotherapy for telangiectasias in the lower limbs is a well consolidated technique in use around the world. In recent years, with the introduction of the dense foam sclerotherapeutic technique accompanied by eco-color-Doppler ${ }^{5-8}$, various angiologists and vascular surgeons have begun to utilize it to treat large caliber varicose veins, including saphenous veins, especially in patients in the more advanced stages of the disease, when dermatoliposclerosis limits surgical treatment.

The goal of chemical sclerosis is not simply to trigger intra-vessel thrombosis, which can undergo absorption with the consequent recanalization of the blood vessel, but also to promote definitive fibrosis of the vessel, which corresponds to surgical treatment of varicose veins ${ }^{9}$.

Dermal pigmentation in chronic venous insufficiency appears to have an important melanin-related component due to the chronic inflammatory reaction to melanocytic stimulation. On the other hand, the most widely accepted theory to explain postsclerotherapy cutaneous hyperpigmentation is that it develops due to the depositing of hemosiderin in the dermis, secondary to extravasion and following the degradation of red blood cells through the treated vessel wall, resulting from the thrombus formed in the lumen of the sclerosed vein.

With the goal of preventing cutaneous hyperpigmentation, it is common to employ, in the post-sclerotherapy period, extrinsic mechanical venous compression in order to reduce or prevent the formation of intra-vessel thrombus.

Despite the recommendation by various authors ${ }^{7,10,11}$ for mechanical compression of the blood vessel, with the use of graduated elastic compression stockings or of elastic or nonelastic bandages following the injection of sclerosing substances into varicose veins in the lower limbs, and in spite of the wide recognition of its efficiency in the treatment of venous and lymphatic diseases ${ }^{12-16}$, there is no consensus regarding the period necessary for the compression to be effective in the prevention or reduction of clots inside blood vessels, nor regarding the best manner in which it should be performed in the post-sclerotherapy period.

In this research, as it was an experimental study on live animals, it was essential to have knowledge of all the procedures that are aimed at the well-being and safety of the animal and of the researcher ${ }^{17-20}$. Therefore, all norms were followed regarding ethical issues related to the proper and responsible handling of the animals.

Considering that the rabbit ears had a uniform thickness and the compression devices utilized exerted a similar compression force, these factors together effectively reduced the possibility of variation in the compression force. The absence of tissue necrosis confirmed that the compression applied was sufficient only to squeeze the vein walls together, while maintaining an uncompromised arterial flow.

The utilization of the Kruskall-Wallis Test for the statistical study of the results for the degree of vein obstruction and the inflammatory intensity in the various compression periods was justified in view of the fact that the samples from the four groups were independent.

The analysis of the results for the effect of the compression period on the degree of venous obstruction by thrombosis showed that there were no significant differences for the sclerosing substance utilized ( $1 \%$ polidocanol), which is the same as was observed in the control ear in which $0.9 \%$ sodium chlorate was utilized. Therefore, in all the groups, including group 0 for which no compression was applied, intra-vessel thrombus formed and the average of the degree of obstruction did not differ between the various periods studied (from 0 to 120 hours). This suggests that the maintenance of venous compression for up to 120 hours did not impede the blood recirculation in the vessel that received the endovenous injection following decompression. Although it is not possible to conclude that the same would occur in the post-sclerosis period in humans, this result points to this possibility. Nevertheless, more studies are necessary in order 
to define the minimum compression period so as to prevent or reduce the formation of thrombus with post-sclerotherapy venous reperfusion.

The analysis of the results for the effect of the compression period on the degree of intensity of the inflammatory process in the blood vessel and neighboring tissues demonstrated that there were no significant differences concerning the sclerosing substance utilized ( $1 \%$ polidocanol), which is the same as was observed in the control ear in which $0.9 \%$ sodium chlorate was used $(\mathrm{p} \geq 0.05)$. In all the groups, including group 0 for which compression was not applied, the average degree of inflammation did not differ between the various compression periods (from 0 to 120 hours) studied here. This result seems to contradict those found in the literature, which attribute an anti-inflammatory action to compression therapy ${ }^{10,21}$. The result of this research, however, showed that the size of the thrombus had a positive and significant relationship with the inflammatory intensity, and also that the degree of vein obstruction by the thrombus was not significantly different in the various compression periods. Thus, it is reasonable to expect that there should not be a significant difference in the inflammatory intensity in the various compression periods as verified.

When the inflammation intensity was compared with the size of the thrombus, it could be seen that there was a positive and significant association between them $(p=0.0007)$. However, the low magnitude of this correlation force $(29.32 \%)$ makes it possible to affirm only that an increase in one of them implies an increase in the other, though the degrees of increase might be different. This finding may have practical applications, as methods that reduce the formation of intra-vessel thrombus, in this line of thought, may lead to a reduction in the inflammatory intensity with all the related benefits.

The dichotomous character in the verification of the presence or absence of hemosiderin was the determining factor for the adoption of a response-to-treatment association study, based on a contingency table study for each one of the compression periods. The method utilized was the Chi-squared Test, given that the samples were independent in relation to one another and their number allowed for a representativeness of approximately $3.3 \%$ for each one.

In the study of the relationship between the presence of thrombus and of hemosiderin, a significant association was observed ( $p=0.0238)$, with the risk attributed to the occurrence of hemosiderin in the presence of thrombus being $35.71 \%$. This result is in agreement with the literature and reinforces the need for the use of methods that prevent or reduce the formation of intra-vessel thrombus in the post-sclerotherapy period.
Considering that mathematical parameters (averages and standard deviations) were not found for the establishment of the sample quantity, it was calculated based on an experimental model and on the expected analysis methods for the data. As was observed, the sample quantity defined was sufficient for all the analyses and guaranteed the methodological progress of this research project.

The scarcity of scientific articles with content similar to that of this present research makes clear the need for further study of the subject. It is necessary to define the mode of compression and the minimum compression period, since the benefits of this conduct following sclerotherapy for varicose veins and telangiectasias in the lower limbs seems to be well founded in the literature.

\section{Conclusions}

- A period of up to 120 hours is not sufficient to prevent blood reperfusion in sclerosed veins following decompression;

- The inflammatory intensity in the vein and neighboring tissues is related to the size of the thrombus in the venous lumen;

- Hemosiderin impregnation in tissues neighboring the blood vessel that received the endovenous injection is related to the presence of thrombus in the venous lumen;

- The degree of inflammation of the blood vessel and neighboring tissues is not related to the compression period and medication administered.

\section{References}

1. Eberhardt RT, Raffetto JD. Chronic venous insufficiency. Circulation. 2005;111:2398-409.

2. Ivo CS, Ivo MB, Salles PGO, Rosário RCV, Nunes TA. Device for craniocervical isolation in rabbits. Acta Cir Bras. 2009;24(4):31620.

3. Dixon MF, Genta RM, Yardley JH, Correa P. Classification and grading of gastritis. The updated Sydney System. International Workshop on the Histopathology of Gastritis, Houston 1994. Am J Surg Pathol. 1996;20(10):1161-81. Review.

4. Warren JR. Gastric pathology associated with Helicobacter pylori. Gastoenterol Clin N Am. 2000;29(3):705-51.

5. Coleridge-Smith P. Foam and liquid sclerotherapy for varicose veins. Phlebology. 2009;24(Suppl 1):62-72.

6. Evangelista SSM. Ecoescleroterapia com microespuma em varizes tronculares primárias. J Vasc Bras. 2006;5(3):167-8.

7. Figueiredo M, Araújo SP, Penha-Silva N. Ecoescleroterapia com microespuma em varizes tronculares primárias. J Vasc Bras. 2006;5(3):177-83.

8. Redondo P, Cabrera J. Microfoam sclerotherapy. Semin Cutan Med Surg. 2005;24:175-83

9. Rabe E, Pannier-Fischer F, Gerlach H, Breu FX, Guggenbichler S, Zabel M. Guidelines for sclerotherapy of varicose veins (ICD 10: I83.0, I83.1, I83.2, and I83.9). Dermatol Surg. 2004:30:687-93. 
10. Goldman MP. How to utilize compression after sclerotherapy. Dermatol Surg. 2002;28(8):860-2.

11. Weiss RA, Sadick NS, Goldman MP Weiss MA. Post-sclerotherapy compression: controlled comparative study of duration of compression and its effects on clinical outcome. Dermatol Surg. 1999;25(2):105-8.

12. Partsch H, Clark M, Mosti G, Steinlechner E, Schuren J, Abel M, Benigni Jean-Patrick, Coleridge-Smith P, Cornu-Thénard A, Flour M, Hutchinson J, Gamble J, Issberner K, Juenger M, Moffatt C, Neumann HAM, Rabe E, Uhl JF, Zimmet S. Classification of compression bandages: practical aspects. Dermatol Surg. 2008;34:1-10.

13. Bhutia SG, Balakrishnan A, Lees T. Varicose veins. J Perioper Pract. 2008;18(8):346-53. Review.

14. Hirsch SA, Dillavou E. Options in the management of varicose veins, 2008. J Cardiovasc Surg (Torino). 2008;49(1):19-26.

15. Partsch H, Flour M, Coleridge Smith P: International Compression Club. Indications for compression therapy in venous and lymphatic disease Consensus based on experimental data and scientific evidence under the auspices of the IUP. Int Angiol. 2008;27:193219.

\section{Correspondence:}

Tarcizo Afonso Nunes

Rua Prof. Estevão Pinto, 637/1104

30220-060 Belo Horizonte - MG Brasil

Phone: (55 31)9983-0110 / 3409-9632

tan@medicina.ufmg.br
16. Weiss RA, Duffy D. Clinical benefits of lightweight compression: reduction of venous-related symptoms by ready-to-wear lightweight gradient compression hosiery. Dermatol Surg. 1999;25(9):701-4.

17. Marques RG, Miranda ML, Caetano CER, Biondo-Simões ML. Rumo à regulamentação da utilização de animais no ensino e na pesquisa científica no Brasil. Acta Cir Bras. 2005;20(3):262-7.

18. Schanaider A, Silva PC. Uso de animais em cirurgia experimental. Acta Cir Bras. 2004;19(4):441-7.

19. Pimenta LG, Silva AL. Ética e experimentação animal. Acta Cir Bras. 2001;16(4):255-60.

20. Petroianu A. Aspectos Éticos nas Pesquisas em Animais. Acta Cir Bras. 1996;11(3):157-64.

21. Kern P, Ramelet Albert-Adrien, Wütschert R, Hayoz D. Compression after sclerotherapy for telangiectasias and reticular leg veins: A randomized controlled study. J Vasc Surg. 2007;45:1212-6.

\section{Acknowledgement}

To Dr. Miguel Houri Neto for his valuable guidance in the statistical analysis of the results.

Conflict of interest: none Financial source: none

Received: November 10, 2010

Review: January 12, 2011

Accepted: February 14, 2011 